\title{
Weather- and Climate-Related Information for Tourism
}

\author{
ANDREAS MATZARAKIS
}

University of Freiburg, Germany

ABSTRACT Weather, climate and tourism are interconnected in many different ways. All of them are of both global and local significance. Weather and/or climate information is of interest for tourists and the tourist industry especially before and during the vacation period. Relevant climate information can be obtained through different media (tourist guide books, Internet, CD, DVD) or through weather services. During vacations, actual weather information is more important than climate information; therefore, climate information does not play an important role in this period. After the vacation period weather and/or climate information are usually no longer required. Examples of available climate information are: air temperature, relative humidity, precipitation, daily sunshine duration and water temperature on a monthly basis. Human biometeorology can offer and supply relevant information (especially in high spatial resolution) about weather/climate conditions, UV-radiation, air pollution and bioclimatic conditions. This climate-related information can be used by tourist industries for the planning of tourism facilities and tourism areas. Atmospheric effects on human health or heat stress can be detected and quantified.

\section{Introduction}

Geographic location, topography, landscape, vegetation and fauna are factors that influence decisions regarding areas to be visited. Weather and climate are two additional factors.

It is a fact that weather/climate and tourism/recreation are interconnected in diverse ways (Lecha and Shackleford, 1997; Shackleford and Olsson, 1995), and, as such, tourists, tour organizers, travel agencies, tourism planners and stakeholders need to be reliably informed about the role of weather and climate. People are usually disappointed about having to cancel a weekend trip for weather reasons. And what experience could be worse than a vacation with continuous rainy days? Travel organizers or tour operators are well aware of the important role weather has in tourism experiences (see Figure 1): rainy summers and winters with less than ideal snow conditions can adversely affect the number of tourists and, consequently, have a major effect on the location and revenues of tourist organizers (Abegg, 1996). 


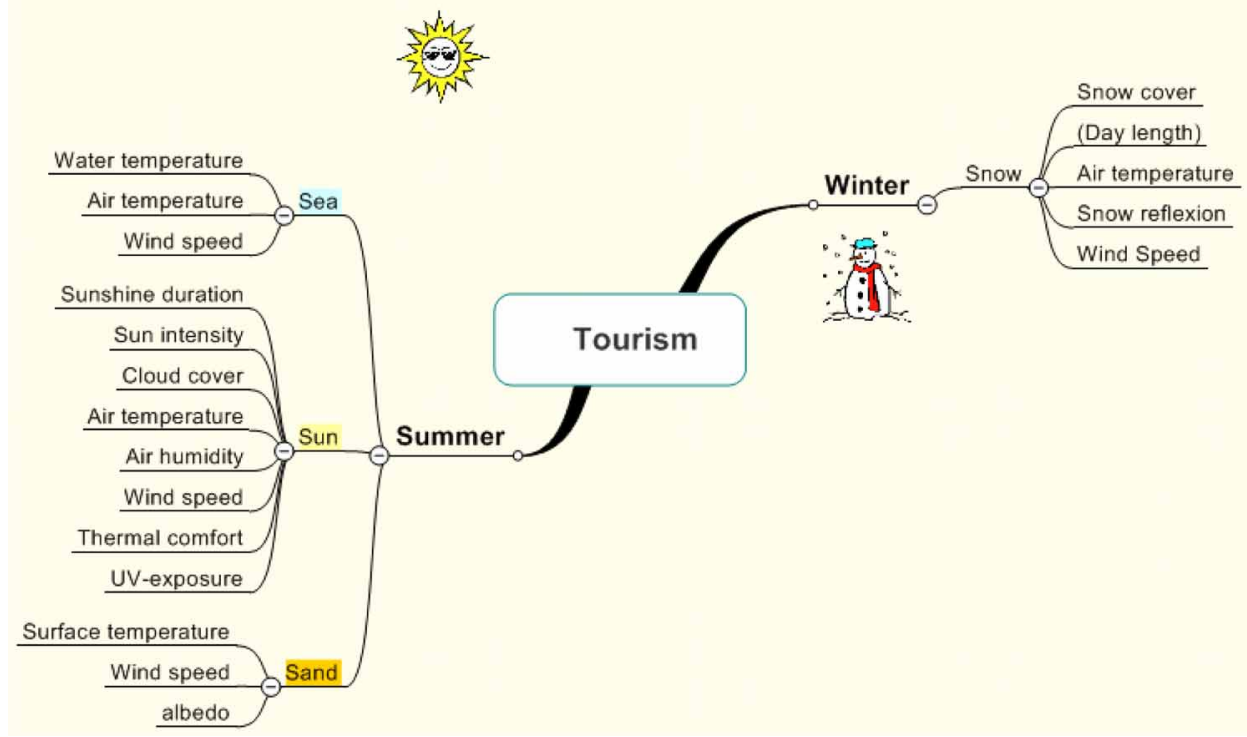

Figure 1. Relations between climate and tourism.

Travel to climate-stressed locations may also result in health problems (e.g. caused by heat stress, UV-radiation, air pollution or heat stroke). A useful climate advisory service will help to prepare and protect travellers and at risk groups (retirees, sick people and children) against the dangers mentioned above. Knowledge of climate information and its application can assist tourism planning, tourism industries and in reducing negative effects of weather and climate on tourists and this branch of the economy.

One aim of this paper is to describe in a useful and understandable way how weather and climate can affect the making of decisions about vacation area and how to access existing information. The second aim is to show what kind of weather/climate information exists and which information is relevant for tourists and the tourism industry.

Since the discussion about climate change and its implications for tourism is still ongoing, an additional aim of this paper is to quantify expected bio-climatological changes. The effects of the thermal environment on humans will be described on a global scale.

The three parts of this paper are: a description of the methods that can be applied, then an evaluation of the existing data, followed by exemplary results for different uses in tourism climatology.

\section{Methods}

Tourism is influenced by many factors; weather and climate are two of them. The interactions of weather and climate in tourism are shown in Figure 1. It is known that tourism, especially summer tourism, can be described by the triple $S$ (sun, sea and sand). Many of the tourism factors creating the triple $S$ are dependent on weather and climate (Figure 1). An additional factor that can be added to the triple S, or used as single winter $S$, is snow, the main decision factor for winter tourism. Figure 1 shows the relevance and importance of weather and climate factors in the tourism sector.

For tourism climatology purposes, methods used in applied climatology and human biometeorology can be employed to address many issues in climate and tourism.

Some useful definitions for an integrated analysis and assessment of weather and climate in tourism climatology are given below. 


\section{Definitions}

Weather is the present combination of atmospheric elements (physical condition of the atmosphere) at a specific time and location, and the resulting processes in the atmosphere (time scale: days, weeks, months).

Climate is the typical representation of atmospheric and weather processes at a location or particular region over a long time period. It is characterized by the distribution of frequencies, mean and extreme meteorological values (time scale: normal period).

Tourism is the entirety of the relationships, phenomena and experiences that arise from travelling and overnight stay of people in locations or areas other than their usual residence.

These three definitions imply different spatial and times scales and they assume complex interactions between the three terms. Weather and climate have the following characteristics in relation to tourism (Abegg, 1996, modified):

1. Weather and climate are limiting factors in tourism. The characteristics of weather and climate can scarcely disrupt human activities absolutely but they constitute a very important financial factor if viewed in the light of tourism. This implies that some regions of the world have a minimal tourism potential, since their climatic conditions do not allow opportunities for tourism. Tourism administrators do not patronize such kinds of area, since this does not yield significant profit. The traveller who nevertheless tours these regions has to deal with high costs (e.g. transport costs) or physical inconvenience (e.g. body strain). Financial loss can also be caused by weather variations and changes. Rainy summers or less snowy winters can have negative consequences for tourism.

2. Weather and climate are dominating factors in tourist demand. Weather and climate shape not only the tourist offers but also the demand. They influence, among other things, the choice of destination or the kind of activities to be carried out. The climatic factors play a significant role in the three phases of a tour: before, during and after. The meteorological conditions also affect the design/construction of the day's schedule.

3. Weather, climate, health and tourism. Trips in climatically stressed areas of the earth can result in health problems (e.g. heat stress, UV-radiation, air pollution and heat stroke). A purposeful climate advisory service can be helpful for the protection of travellers and particularly risk groups (elderly people, sick people and children).

\section{Identification of Data Sources and Information}

Tourism climatology and climate change issues require weather and climate data at different temporal and spatial scales. Sources of meteorological and climatological data include national weather services, private weather services, environmental agencies and governmental authorities running their own measurement networks.

Other sources are tourism guidebooks and the Internet. Data from these sources have very little temporal or spatial detail (Table 1). Climate information from the Internet often describes only current conditions or the forecast for the next few days. Some tourism providers offer weather information for the next few days and general information for a range of tourism destinations.

From a meteorological perspective, synoptic data are provided by national weather services for weather forecasts. The data provide details of many parameters, with a high degree of temporal availability, but often do not have the appropriate spatial resolution 
Table 1. Climate values for Santorini/Greece taken from a tourism guidebook (Adams, 1996)

\begin{tabular}{lcccccc}
\hline & $\begin{array}{c}\text { Mean air } \\
\text { temperature } \\
\left({ }^{\circ} \mathrm{C}\right)\end{array}$ & $\begin{array}{c}\text { Mean maximum } \\
\text { air temperature } \\
\text { Month }\end{array}$ & $\begin{array}{c}\text { Sunshine } \\
\text { duration/day }\end{array}$ & $\begin{array}{c}\text { Precipitation } \\
(\mathrm{mm})\end{array}$ & $\begin{array}{c}\text { Relative } \\
\text { humidity } \\
(\%)\end{array}$ & $\begin{array}{c}\text { Water } \\
\text { temperature }\end{array}$ \\
\hline Jan. & 11 & 15 & 4 & 74 & 74 & 16 \\
Feb. & 11 & 16 & 5 & 52 & 73 & 15 \\
Mar. & 12 & 17 & 5 & 41 & 72 & 15 \\
Apr. & 15 & 20 & 8 & 21 & 71 & 16 \\
May & 19 & 24 & 10 & 12 & 69 & 19 \\
June & 22 & 28 & 11 & 2 & 65 & 22 \\
July & 25 & 29 & 13 & 0.1 & 61 & 24 \\
Aug. & 25 & 29 & 9 & 1.5 & 60 & 25 \\
Sept. & 22 & 27 & 7 & 9 & 68 & 23 \\
Oct. & 19 & 23 & 6 & 52 & 72 & 21 \\
Nov. & 16 & 20 & 4 & 74 & 74 & 19 \\
Dec. & 13 & 16 & & & & \\
\hline
\end{tabular}

for tourism climatology. From a spatial perspective, climate networks contain more stations, but not all stations collect the same kind of data on a regular basis (Table 2). The quality and quantity of climate information differs from one country to another. Both, synoptic and climatological data are partially used for tourism purposes.

From the multitude of meteorological and climatological parameters measured the most relevant for tourism are:

- Air temperature

- Air humidity

- Wind speed

- Wind direction

Table 2. Climate parameters for Santorini taken from the Greek climate network on a monthly basis (Andreakos, 1978)

\begin{tabular}{llll}
\hline Parameter & Data & \multicolumn{1}{c}{ Mean value of days of } & Data \\
\hline Air pressure $(\mathrm{hPa})$ & Yes & Precipitation & Yes \\
Mean air temperature $\left({ }^{\circ} \mathrm{C}\right)$ & Yes & Rain & Yes \\
Mean max. air temperature $\left({ }^{\circ} \mathrm{C}\right)$ & Yes & Snow & Yes \\
Mean min. air temperature $\left({ }^{\circ} \mathrm{C}\right)$ & Yes & Snow rain & No \\
Absolute max. air temperature $\left({ }^{\circ} \mathrm{C}\right)$ & Yes & Rainstorm & Yes \\
Absolute min. air temperature $\left({ }^{\circ} \mathrm{C}\right)$ & Yes & Hail & Yes \\
Absolute mean max. air temp. $\left({ }^{\circ} \mathrm{C}\right)$ & Yes & Snow cover & Yes \\
Absolute mean min. air temp. $\left({ }^{\circ} \mathrm{C}\right)$ & Yes & Fog & No \\
Mean relative humidity $(\%)$ & Yes & Dew & Yes \\
Mean precipitation $(\mathrm{mm})$ & Yes & Frost & Yes \\
Maximum precipitation in $24 \mathrm{~h}(\mathrm{~mm})$ & Yes & Mean min. air temp. $<0.0{ }^{\circ} \mathrm{C}$ & Yes \\
Mean cloud cover $(\mathrm{Octas})$ & Yes & Mean max. air temp. $<0.0{ }^{\circ} \mathrm{C}$ & No \\
Sunshine duration $(\mathrm{h})$ & No & Wind speed $>6 \mathrm{Bft}$ & Yes \\
Cloud cover $(0-1.5) / 8$ & Yes & Wind speed $>8 \mathrm{Bft}$ & Yes \\
Cloud cover $(6-8) / 8$ & Yes & Wind direction & Yes \\
& & Mean wind speed in Bft & Yes \\
\hline
\end{tabular}


- Cloud cover

- Sunshine duration or radiation fluxes

- Rain and precipitation

- (Snow cover)

- (Water temperature)

From a human-biometeorological point of view, it is not so easy to list the most relevant parameters for tourism. In the case of summer tourism, the air temperature can be the most important factor. But air temperature is most relevant for a temperature range lying in the area of thermal comfort so information about the thermal perception and physiological strain are more relevant. In most cases, though, the knowledge of air temperature and precipitation provide very helpful information. For winter tourism, the most relevant information is snow cover.

Showing or presenting single climatological parameters does not represent the actual scientific status quo.

\section{Assessment of Data and Information}

Data, metadata and extracted information, as well as the presentation and transfer of this relevant and required information for tourism purposes, are the main factors in tourism climatology (Figure 2a and 2b).

In the past, tourism climatology information was provided through climate indices such as those found in applied climatology and human-biometeorology. There are more than 200 climate indices. In general, the tourism climate indices can be classified into three categories (after Abegg, 1996, modified). Elementary indices are synthetic values that do not have any thermo-physiological relevance and are generally unproven. The bioclimatic and combined tourism climate indices involve more than one climatological parameter and consider the combined effects of these. Some examples of tourism climate indices are provided in Table 3.

One example of an elementary climate index is the Climate Index by Davies (1968) (equation 1). This index encompasses a number of variables for the period from June to August, including mean daily maximum air temperature $\left(\mathrm{T}_{\mathrm{amax}}\right)$, sunshine duration $(\mathrm{S})$ and the total precipitation $(\mathrm{N})$.

$$
\mathrm{I}=18^{*} \mathrm{~T}_{\mathrm{amax}}+0.217^{*} \mathrm{~S}-0.276^{*} \mathrm{~N}+320
$$

An example of a combined index is the Tourism Climate Index (TCI). Developed by Mieczkowski (1985), the TCI uses a combination of seven parameters, three of which are independent and two in a bioclimatic combination (equation 2).

$$
\mathrm{TCI}=8^{*} \mathrm{Cld}+2^{*} \mathrm{Cla}+4^{*} \mathrm{R}+4^{*} \mathrm{~S}+2^{*} \mathrm{~W}
$$

Where Cld is a daytime comfort index, consisting of the mean maximum air temperature $\mathrm{T}_{\mathrm{a}, \max }\left({ }^{\circ} \mathrm{C}\right)$ and the mean minimum relative humidity $\mathrm{RH}(\%), \mathrm{Cla}$ is the daily comfort index, consisting of the mean air temperature $\left({ }^{\circ} \mathrm{C}\right)$ and the mean relative humidity $(\%), \mathrm{R}$ is the precipitation $(\mathrm{mm}), \mathrm{S}$ is the daily sunshine duration $(\mathrm{h})$ and $\mathrm{W}$ is the mean wind speed $(\mathrm{m} / \mathrm{s})$. In contrast to other climate indices, every contributing parameter is assessed. Because of a weighting factor (a value for TCI of 100), every factor can reach 5 points. TCI values $>=80$ are excellent, while values between 60 and 79 are regarded as good to very good. Lower values (40-59) are acceptable, 
(a) Corfu

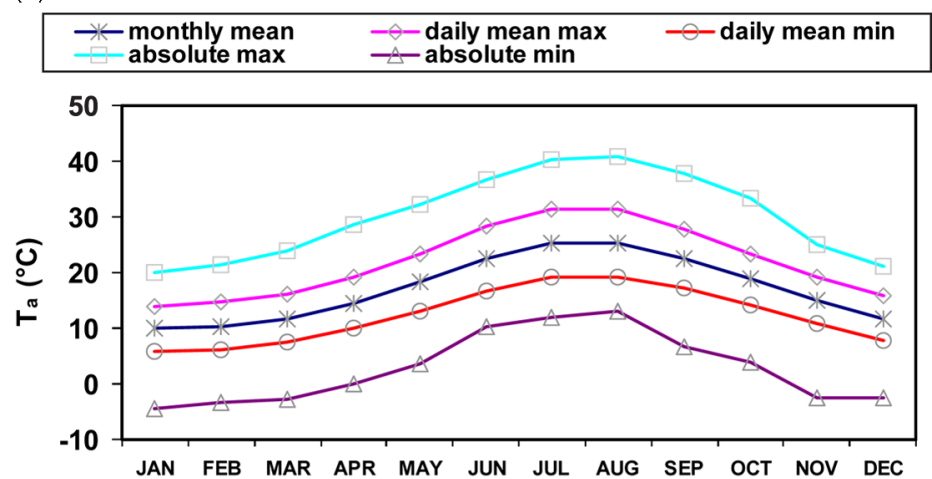

(b)

Corfu

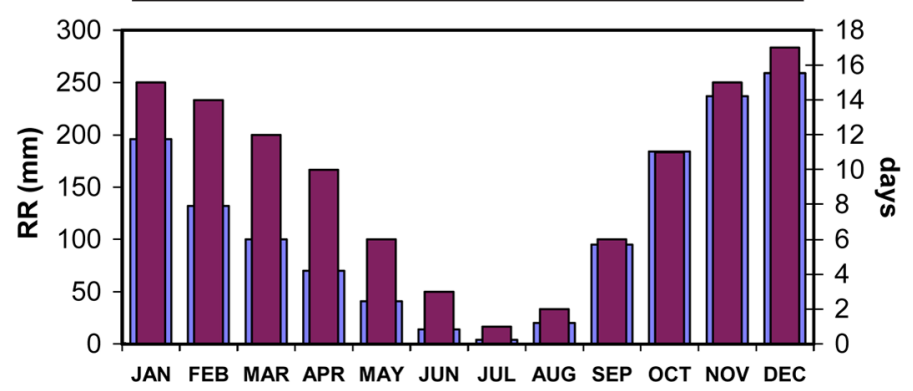

Figure 2. (a) Examples of climate data analysis (air temperature $\mathrm{T}_{\mathrm{a}}$ ). (b) Examples of climate data analysis (precipitation RR and frequency of days with a precipitation greater than $0.1 \mathrm{~mm}$ ).

but values $<40$ indicate bad or difficult conditions for tourism (Abegg, 1996; Mieczkowski, 1985).

The climatic indices shown have a number of weaknesses. From a climatology point of view, they do not include the effects of short- and long-wave radiation fluxes, since these are generally not included in climatic records. The required short- and long-wave radiation fluxes are calculated using synoptic data and theoretical calculations from astronomical data (VDI, 1998; Matzarakis et al., 2000). A full application of thermal indices on the energy balance of the human body gives detailed information of the effect of the thermal environment on humans (VDI, 1998). Common applications are PMV (predicted mean vote), PET (physiologically equivalent temperature) (Matzarakis and Mayer, 1997; VDI, 1998; Höppe, 1999; Matzarakis et al., 1999), SET* (standard effective temperature) (in Matzarakis, 2001) and pT (perceived temperature) (Matzarakis, 2001; Tinz and Jendritzky, 2003). All those thermal indices are well documented and include important meteorological and thermo-physiological parameters (Matzarakis, 2001).

The advantage of these thermal indices is that they all require the same meteorological input parameters: air temperature, air humidity, wind speed, short- and long-wave radiation fluxes. In Table 4, threshold values of the thermal indices predicted mean vote (PMV) and physiologically equivalent temperature (PET) are explained for different levels of thermal sensitivity and physiological stress of humans. Internal heat production: $80 \mathrm{~W}$, heat transfer resistance of clothing: 0.9 clo (according to Matzarakis and Mayer, 1996) giving the possibility of accessing the thermal environment of humans (Table 4). 
Table 3. Tourism climate indices (after Abetz, 1996, modified)

\begin{tabular}{|c|c|c|}
\hline Category & Parameters included & Authors \\
\hline Elementary & $\begin{array}{l}\text { Air temperature, sunshine duration, } \\
\text { precipitation (synthetic values) }\end{array}$ & $\begin{array}{l}\text { Besancenot (1990) } \\
\text { Davis (1968) } \\
\text { Poulter (1962) } \\
\text { Fergusson (1964) } \\
\text { Rackliff (1965) } \\
\text { Hughes (1967) } \\
\text { Murray (1972) }\end{array}$ \\
\hline Bioclimatic & $\begin{array}{l}\text { Windchill (air temperature, wind } \\
\text { speed) Indices - based on human- } \\
\text { energy balance } \\
\text { i.e. predicted mean vote } \\
\text { standard effective temperature } \\
\text { physiological equivalent temperature }\end{array}$ & $\begin{array}{l}\text { Terjung (1969) } \\
\text { Fanger (1972) } \\
\text { Yapp and McDonald } \\
\text { (1978) } \\
\text { Reifsnyder (1983) } \\
\text { Gagge } \text { et al. (1986) } \\
\text { De Freitas (1990) } \\
\text { Höppe (1999) } \\
\text { De Dear and Pickup } \\
\text { (1999) } \\
\text { Blazejczyk (2001) }\end{array}$ \\
\hline Combined & $\begin{array}{l}\text { Combination of parameters and } \\
\text { factors Cld, Cla, RR, SD, v, PET or } \\
\text { PMV, RR }\end{array}$ & $\begin{array}{l}\text { Mieczkowski (1985) } \\
\text { Heurtier (1968) } \\
\text { Matzarakis and Moya } \\
(2002)\end{array}$ \\
\hline
\end{tabular}

Notes: Cld: daytime comfort index, Cla: daily comfort index, RR: precipitation, SD: sunshine duration, v: wind speed, PET: physiological equivalent temperature, PMV: predicted mean vote

The thermal environment of humans can be altered by parameters such as 'internal heat production' (e.g. $80 \mathrm{~W}$ ) and 'heat transfer resistance of clothing' (e.g. 0.9 clo).

The thermal indices mentioned above (PET, PMV and SET*) can be calculated with existing model/software packages, which are freely available, i.e. RayMan Model (Matzarakis et al., 2000; Matzarakis, 2002). They are suitable for the evaluation of the thermal environment not only for summer conditions, but also throughout the year.

\section{Exemplary Results}

In general, the availability of national climatic networks of basic meteorological and climatological data is required. Data needed for some bioclimatic purposes are generally available; however, the spatial resolution is not sufficient for tourism-related analysis (Matzarakis and de Freitas, 2001).

Some examples and results that may be useful for various purposes in tourism climatology are now presented. The application of the energy balance of the human body and the derived thermal index (PET) on a global scale imposes stringent requirements on data and calculations. Based on the HadCM3 model, which produces data in a spatial resolution of $2.5^{\circ}$ latitude and $3.75^{\circ}$ longitude (Johns et al., 2003; New et al., 1999, 2000, 2002) and on the monthly mean values of air temperature, relative humidity, wind speed and cloud cover for the climate normal period (1961-90), which are the meteorological input parameters for PET, the mean monthly values for PET have been calculated by the radiation and bioclimate model RayMan 
Table 4. Threshold values of predicted mean vote (PMV) and physiologically equivalent temperature (PET) indices for levels of thermal sensitivity and physiological stress in humans. Internal heat production: $80 \mathrm{~W}$, heat transfer resistance of clothing: 0.9 clo (according to Matzarakis and Mayer, 1996)

\begin{tabular}{|c|c|c|c|}
\hline PMV & PET & $\begin{array}{l}\text { Thermal } \\
\text { sensitivity }\end{array}$ & $\begin{array}{c}\text { Grade of physiologica } \\
\text { stress }\end{array}$ \\
\hline & & Very cold & Extreme cold stress \\
\hline-3.5 & $4^{\circ} \mathrm{C}$ & Cold & Strong cold stress \\
\hline-2.5 & $8^{\circ} \mathrm{C}$ & $\begin{array}{l}\text { Cool } \\
\text { C------------ }\end{array}$ & Moderate cold stress \\
\hline-1.5 & $13^{\circ} \mathrm{C}$ & Slightly cool & Slight cold stress \\
\hline-0.5 & $18^{\circ} \mathrm{C}$ & Comfortable & No thermal stress \\
\hline 0.5 & $23^{\circ} \mathrm{C}$ & Slightly warm & Slight heat stress \\
\hline 1.5 & $29^{\circ} \mathrm{C}$ & Warm & Moderate heat stress \\
\hline 2.5 & $35^{\circ} \mathrm{C}$ & Hot & Strong heat stress \\
\hline 3.5 & $41^{\circ} \mathrm{C}$ & Very hot & Extreme heat stress \\
\hline
\end{tabular}

(Matzarakis et al., 2000). Figure 3 shows the global distribution of PET for January (top pane) and July (bottom pane). The classes in Figure 3 are according to Table 4 and represent the different ranges of PET, thermal sensitivity and physiological strain of humans. The geographical distribution of PET, an index for the effect of the thermal environment on humans, for the Mediterranean is highly significant. The region is one of the most popular tourism destinations, lying during the winter time in the comfort and cold stress regions. During summer (July), the thermal bioclimatic conditions range from light heat stress to extreme heat stress conditions. It is a fact that visitors to summer tourism destinations often suffer from heat stress and the negative implications or health effects.

Additional time slices have been run for different Second Report Emision Scenarios (SRES) (IPCC, 2000) scenarios, which involved an exploration of possible changes in socio-economic conditions and population. From these, Green House Gas (GHG) emissions and atmospheric concentrations of these greenhouse gases could be estimated, which in turn have been used to explore the response of the climate conditions for the future. This dataset of the future climatic state has been based on the integration of the HadCM3 model forced with the standard SRES emission scenarios (A1F, A2A, B1A and B2A) for the time period 2070-99. Figure 4 shows the global distribution of PET for the A1F emission scenario for the time slice 2070-100 for January (top pane) and July (bottom pane). The results demonstrate that the PET conditions, based on the A1F and A2A scenarios (not shown here), will be much worse in the future. A comparison of the geographical distribution of PET (Figures 3 and 4) shows that this will mainly 


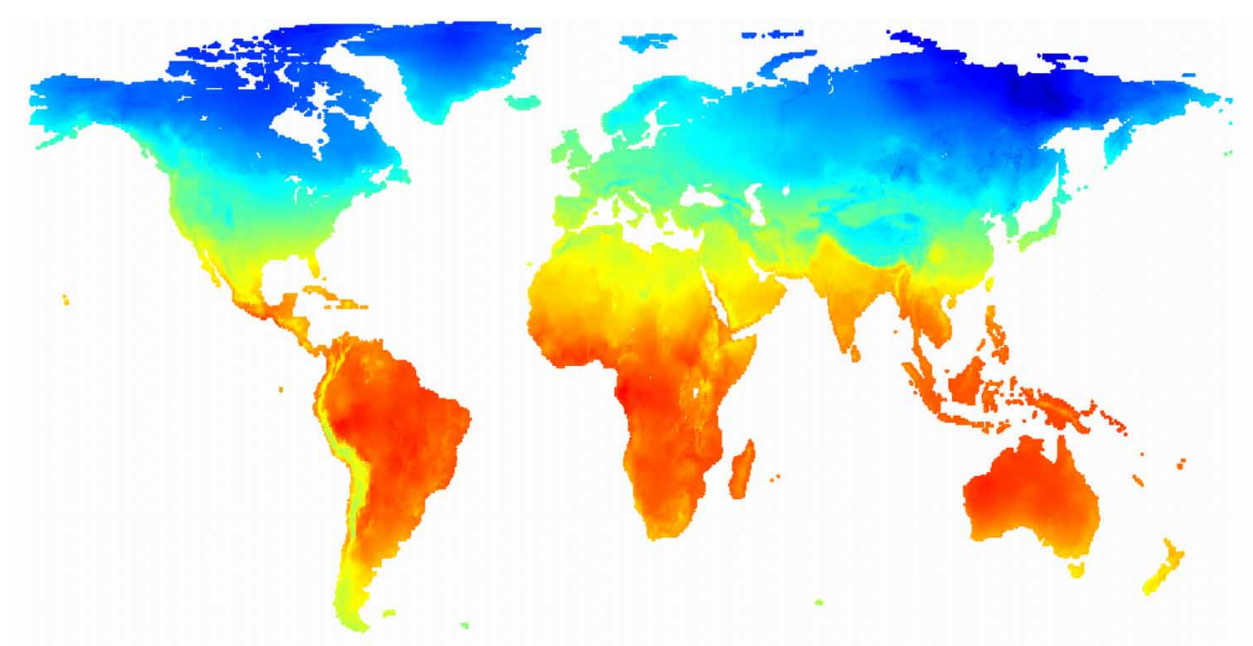

\begin{tabular}{rc|c|c|c|c|c|c|c|c|c|c|c|c|c|c|c|c|c|}
\hline & & & & & & & & & & & & & & & $\mid$ & & & \\
-60 & -50 & -40 & -30 & -20 & -10 & 0 & +10 & +20 & +30 & +40 & +50 & +60
\end{tabular}
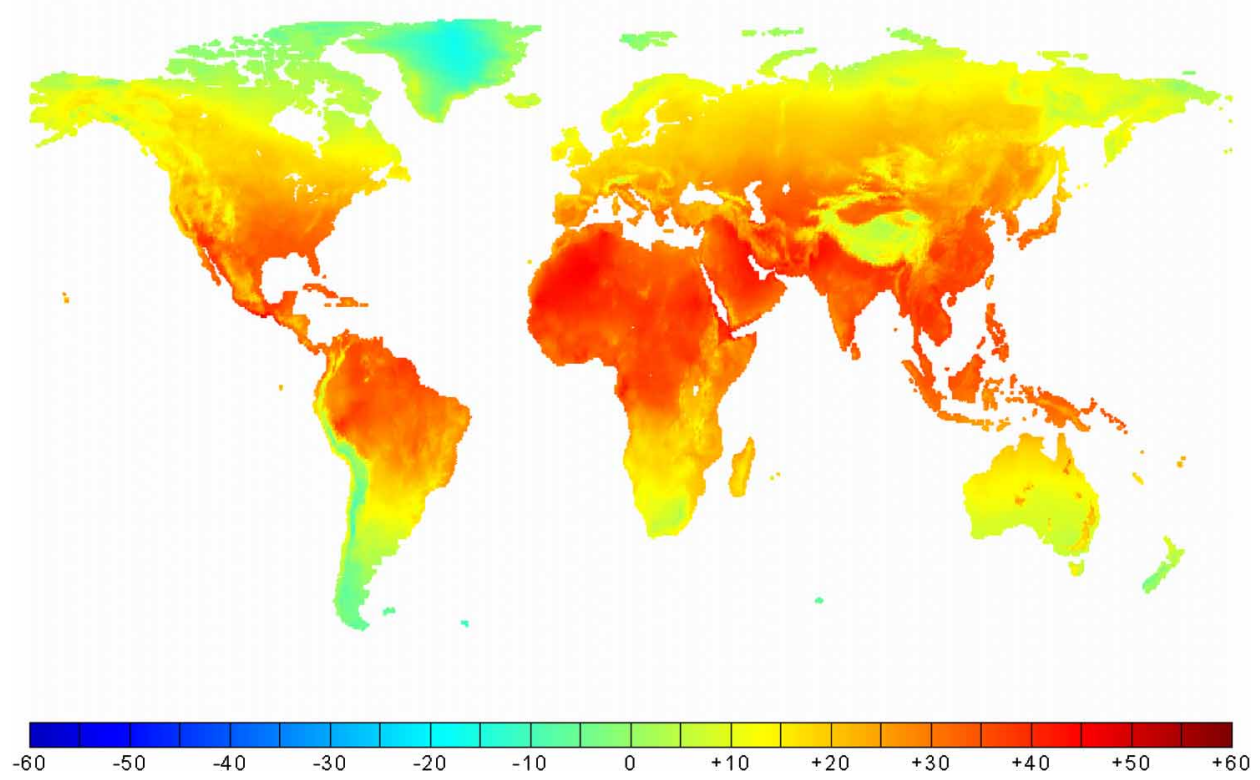

Figure 3. Global distribution of PET for the period 1961-90 for January (top pane) and July (bottom pane).

affect very popular summer tourism areas, in which the tourism industry is the backbone of the local economy. The analysis reveals that areas experiencing extreme heat stress conditions (PET $>35^{\circ} \mathrm{C}$ ) will increase significantly. As a consequence, visitors will look for other, more thermally comfortable regions. In comparison to the A1F scenario for the time slice 2070-99 and the climate normal period (1961-90), it results that during July the areas with PET $>35^{\circ} \mathrm{C}$ in the northern hemisphere will increase. The information shown regarding climate change outputs from global circulation models, i.e. air temperature or perceived temperature (Tinz and Jendritzky, 2003) or PET (Figures 3 and 4), can be 

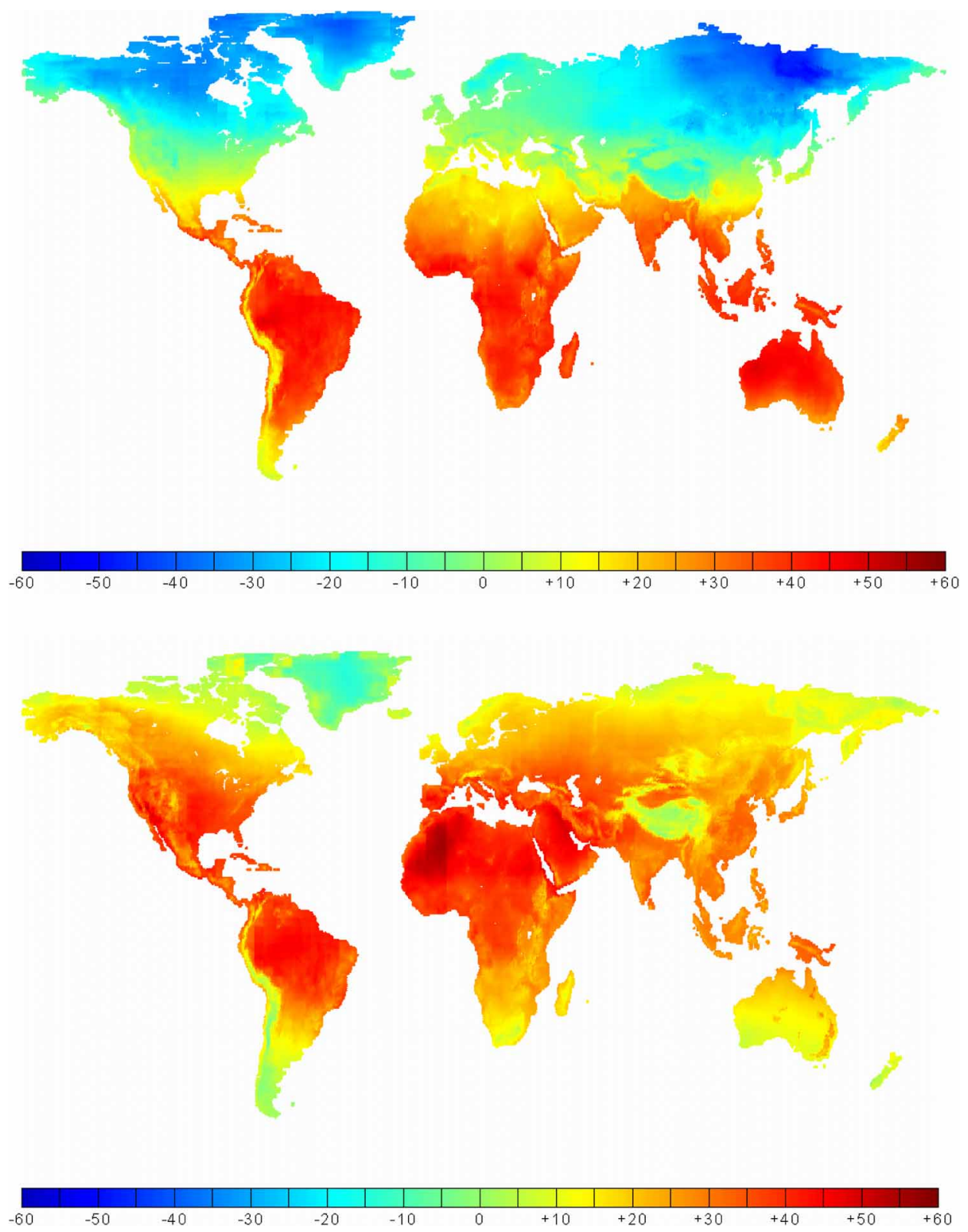

Figure 4. Global distribution of PET for the A1F emission scenario for the period 2070-99 for January (top pane) and July (bottom pane).

helpful for tourism and provide additional information mainly due to the coarse spatial resolution. Tourism climate information is also relevant at the meso- and micro-scale for different purposes of the tourism industry.

As an example, Figure 5 shows an implementation of PET, an application for the Mediterranean climate. Mean, high and low PET values at 12 UTC per day at Corfu, Greece, are given for the period from 1980 to 1989. This illustration provides information about the variation of PET on a daily basis during the period under investigation. The results in Figure 5 show that cold stress $\left(\mathrm{PET}<18^{\circ} \mathrm{C}\right.$ ) occurs mainly 


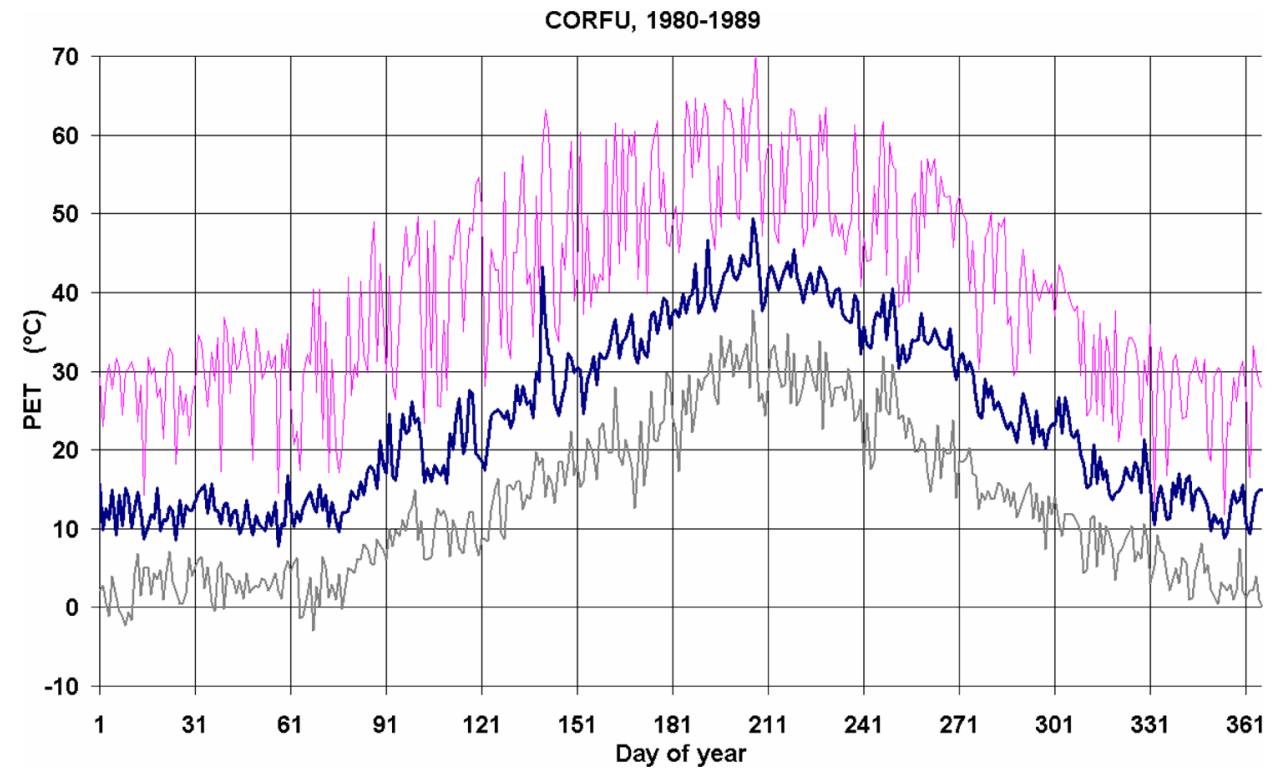

Figure 5. Mean, highest and lowest daily values of the physiologically equivalent temperature (PET) at Corfu at 12 UTC for the years 1980-9.

from October to April. Mean PET values over $30^{\circ} \mathrm{C}$, which occur between June and September, indicate at least moderate heat stress. On some hot summer days between May and September, PET calculated for 12 UTC was over $40^{\circ} \mathrm{C}$, thus representing a pronounced thermal stress situation on Corfu Island.

The link between station data, such as air temperature or PET, can be performed by the construction of maps. Climatic and bioclimatic maps can be constructed using a statistical model, which uses the application of multiple linear regressions. The input data consist of dependent variables, such as air temperature or physiological equivalent temperature of climate/synoptic stations, and independent variables, including latitude, longitude, elevation above the sea level, shortest distance of each grid cell to the sea (as an indicator for continental climate) and a factor of land/sea coverage in percentages for parts of the area with a diameter of approximately $40 \mathrm{~km}$ (Matzarakis and Mayer, 1997).

Figure 6 shows the geographical distribution of PET for July. The figure shows the differences between the inner mainland of Greece, the coast and the Greek islands. In July, the conditions on the Greek islands are quite comfortable and the PET values are less than those in the inner parts of Greece. In order to identify areas with the possibility of heat stress, the frequencies of days with PET $>29^{\circ} \mathrm{C}$ for Greece are given in Figure 7. Areas with a high heat stress potential coincide with population agglomerations and tourism centres. This kind of information can assist in planning of new tourism resorts, the extension or reduction of tourism periods, and the minimization of health implications for tourists during periods with heat stress.

\section{Discussion}

A minority of the climate and bioclimate indices still in use are useful for tourism purposes. This is because they do not include all the relevant parameters for the assessment 


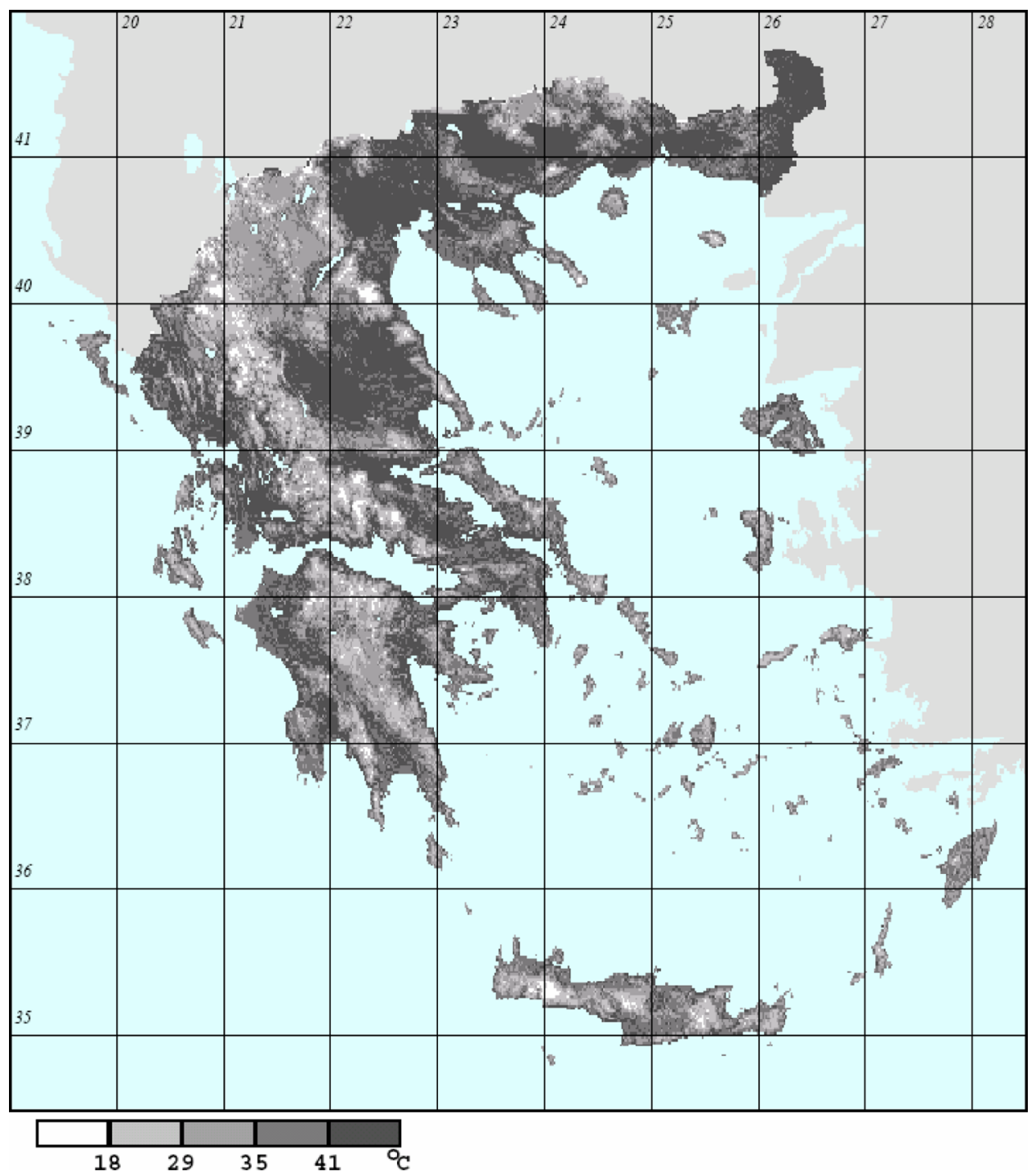

Figure 6. Geographical distribution of PET in Greece for July.

of weather or climate relevant for tourism. Most of the regular climate indices are based only on air temperature and air humidity; they do not include thermal comfort or thermal stress conditions. Furthermore, they are either formulated on a monthly basis or they can be used only for the summer months. Thus, they cannot be used for analysis of detailed weather and tourism relationships.

Human-biometeorology provides well-suited thermal indices on the basis of the human energy balance for the assessment of the thermal environment for human beings on a regional, local and global scale for current and future climatic conditions. This information can be implemented in both planning and construction of tourism areas and facilities.

The advantages of the human-biometeorological indices are that they all require the same input parameters (air temperature, air humidity, wind speed as well as short- and 


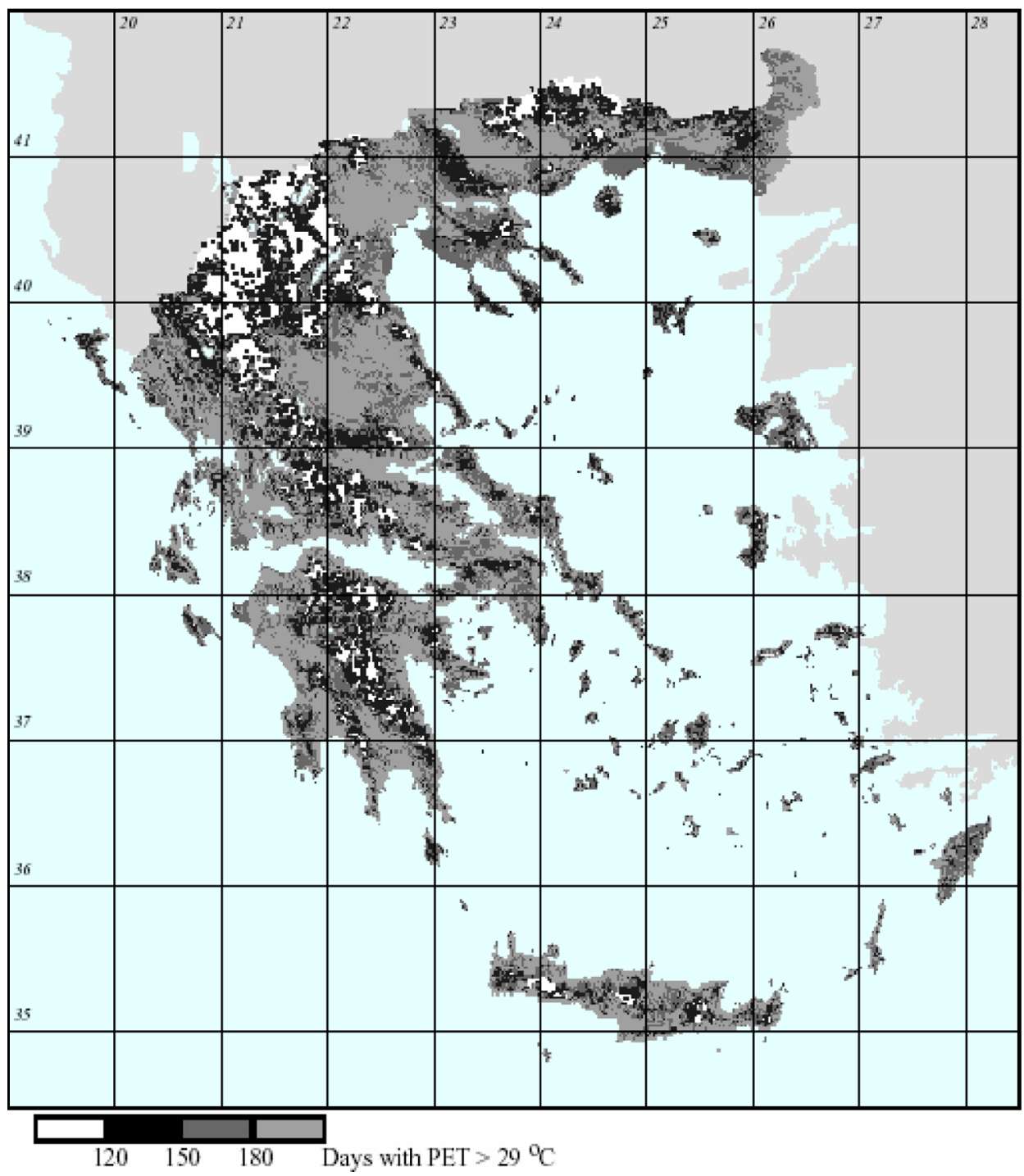

Figure 7. PET frequencies (days with PET $>29^{\circ} \mathrm{C}$ ) for Greece.

long-wave radiation fluxes). A range of climate information is needed for tourism climatology, but single meteorological or climatological parameters in the form of means (Figure 5), extremes (Figure 6), frequencies (Figure 7) and probabilities may be less relevant on their own (Harlfinger, 1991; Giles and Perry, 1998; Matzarakis, 2002; de Freitas, 2003).

Applying climatology and human-biometeorology to tourism-relate issues also leads to questions about the existing data or information. One question is about how appropriate the existing data are for use by tourists and tourism planners. Are the data appropriate and relevant for tourism planning and are the data available (Matzarakis, 2001)?

Climate data and assessed climate information for tourism require a quantitative and not only qualitative character (Figures 6 and 7). Combined effects of atmospheric parameters, like thermal comfort, are of interest, but they do not provide an absolute detailed integral 


\section{A. Matzarakis}

Table 5. Various facets of tourism climate and their significance and impact (de Freitas, 2001, 2003, modified)

\begin{tabular}{|c|c|c|}
\hline Facet of climate & Significance & Impact \\
\hline \multicolumn{3}{|l|}{ Aesthetic } \\
\hline Sunshine/cloudiness & Quality of experience & Enjoyment, attractiveness of site \\
\hline Visibility & Quality of experience & Enjoyment, attractiveness of site \\
\hline Day length & Convenience & Hours of daylight available \\
\hline \multicolumn{3}{|l|}{ Physical } \\
\hline Wind & Annoyance & Blown belongings, sand, dust ... \\
\hline Rain & Annoyance, charm & Wetting, reduced visibility, enjoyment \\
\hline Snow & Winter sports/activities & Participation in sports/activities \\
\hline Ice & Danger & Personal injury, damage to property \\
\hline Severe weather & Annoyance, danger & All of above \\
\hline Air quality & Annoyance, danger & Health, physical well-being, allergies \\
\hline Ultraviolet radiation & Danger, attraction & Health, suntan, sunburn \\
\hline Odours & Annoyance & Attractiveness of site \\
\hline Noise & Annoyance & Attractiveness of site \\
\hline \multicolumn{3}{|l|}{ Thermal } \\
\hline \multirow{5}{*}{$\begin{array}{l}\text { Integrated effects of air temperature, } \\
\text { wind, solar radiation, humidity, long } \\
\text { wave radiation, metabolic rate, } \\
\text { clothing. }\end{array}$} & Thermal comfort & Environmental stress \\
\hline & & Physiological strain \\
\hline & & Hypothermia \\
\hline & & Hyperthermia \\
\hline & Therapeutic, restorative & Potential for recuperation \\
\hline
\end{tabular}

assessment of the effects of the atmosphere on humans or assessment about the planning of new tourism resorts and so on (see Table 4). Physical factors, such as ultraviolet radiation or air quality have to be included in the assessments. For example, sunshine or visibility is important for the aesthetic component. In order to be widely used in tourism climatology, information on climate (including all atmospheric and physical terms) requires wellprepared and presented information (de Freitas, 1990, 2001).

Tourism climate indices and, in general, thermal climate indices are not evaluated by specialists and tourists and they do not include the climate adaptation of humans. Thus, climate adaptation is to be investigated in the future (Koppe and Jendritzky, 2003) with regard to health implications and potential damages.

An example of the various facets of their significance and impacts is given in Table 5, including most of the relevant climatic factors. Other interactions between the different aspects, including recreational behaviour and socio-economic factors, have to be taken into consideration (de Freitas, 2003).

\section{Conclusions}

Many sources of weather and climate data or information (measured or modelled) are available to the public. Therefore, climate-relevant information can be implemented by tourism demands. A number of important conclusions regarding climate data and tourism are given below.

Climate information has to be calculated and provided for tourism planning and tourism industry using mean values, extremes, frequencies, probabilities, with some indication of their possible effects and implications. Single parameters (i.e. air temperature) are inadequate for tourism climatology. 
The impacts of climate and climate information can also be assessed from the humanbiometeorology point of view. The thermal component is the main factor that determines the desirability of weather and climate. The knowledge of thermal bioclimatic conditions, from global resolution down to local conditions of tourism areas, is of interest and valid for the tourism industry and governmental authorities. This knowledge can be helpful not only for existing and planned tourism resorts and areas, but also in providing information about areas and periods where tourists may be affected negatively by weather and climate conditions. Outputs from climate models, like the results of HadCM3, offer a possibility for the calculation of future bioclimatic conditions like PET. They do not give information only about the quality of bioclimatic changes, but also about the quantification of the bioclimatic changes for tourism destinations. The extracted results based on the emission scenarios show that many current tourism destinations will suffer from bioclimatic change conditions. This will have a significant impact on local economies in the near future.

The way humans adapt to different climatic conditions has to be identified and scientifically proven. Evaluation of the value of tourism climate indices or thermal indices has not yet been undertaken.

Assessments have to integrate implications and interactions, not only from the climatological point of view but also from the socio-economic and behavioural aspects of tourism. In the absence of ideal conditions, a personally acceptable microclimate/bioclimate can be created.

Finally, looking at the existing deficits and observing critical points, it should be mentioned that the Commission on Climate, Tourism and Recreation of the International Society of Biometeorology (http://www.mif.uni-freiburg.de/isb) is working on the development of scientific tools for tourism climatology.

\section{Acknowledgements}

Thanks to Bas Amelung from the Institute of Integrative Studies, University of Maastricht, for providing and preparing the input data for the global runs analysis. Thanks to Markus Zygmuntowski for the global maps produced by IDL software. Thanks to Nikola Sander for proofreading and editing the manuscript.

\section{References}

Abegg, B. (1996) Klimaänderung und Tourismus (Zürich: Schlussbericht NFP 31. vdf Hochschulverlag AG an der ETH).

Adams, N. (1996) Santorini, 2nd edition (Köln, Dumont).

Andreakos, K. (1978) Climatic Data of the Greek Network: Period 1930-1975 (Athens: National Hellenic Weather Service).

Besancenot, J.-P. (1990) Climat et tourisme (Paris: Collection géographie).

Blazejczyk, K. (2001) Assessment of recreational potential of bioclimate on the human heat balance, in: A. Matzarakis and C. R. de Freitas (Eds) Proceedings of the First International Workshop on Climate, Tourism and Recreation, International Society of Biometeorology, Commission on Climate Tourism and Recreation, pp. 133-52.

Davies, N. E. (1968) An optimum summer weather index, Weather, 23, pp. 305-17.

De Dear, R. and Pickup, J. (1999) An outdoor thermal comfort index (OUT_SET*), Part II, Applications, in: R. J. de Dear, J. D. Kalma, T. R. Oke and A. Auliciems (Eds) Biometeorology and Urban Climatology at the Turn of the Millennium, Selected Papers from the Conference ICB-ICUC'99, Sydney, WCASP-50, WMO/TD No. 1026, pp. 285-90.

De Freitas, C. R. (1990) Recreation climate assessment, International Journal of Climatology, 10, pp. 89-103. 


\section{A. Matzarakis}

De Freitas, C. R. (2001) Theory, concepts and methods in climate tourism research, in: A. Matzarakis and C. R. de Freitas (Eds) Proceedings of the First International Workshop on Climate, Tourism and Recreation, International Society of Biometeorology, Commission on Climate Tourism and Recreation, pp. 3-20.

De Freitas, C.R. (2003) Tourism climatology: evaluating environmental information for decision making and business planning in the recreation and tourism sector. International Journal of Biometeorology, 48, pp. 45-54.

Fanger, P. O. (1972) Thermal Comfort (New York: McGraw-Hill).

Fergusson, P. (1964) Summer weather at the English seaside, Weather, 19, pp. 144-6.

Gagge, A. P., Fobelets, A. P. and Berglund, L. G. (1986) A standard predictive index of human response to the thermal environment, ASHRAE Trans, 92, pp. 709-31.

Giles, A. and Perry, A. H. (1998) The use of temporal analogue to investigate the possible impact of the projected global warming on the UK tourist industry, Tourism Management, 19, pp. 75-80.

Harlfinger, O. (1991) Holiday bioclimatology: a study of Palma de Majorca, Spain, Geo Journal, 25, pp. 377-81.

Heurtier, R. (1968) Essai de climatologie touristique synoptique de l'Europe occidentale et méditerranéenne pendant la saison d'éte, La Météorologie, 5, pp. 71-107, 519-66.

Höppe, P. (1999) The physiological equivalent temperature - a universal index for the biometeorological assessment of the thermal environment, International Journal of Biometeorology, 43, pp. 71-5.

Hughes, G. H. (1967) Summers in Manchester, Weather, 22, pp. 199-200.

IPCC (2000) Emission Scenarios: A Special Report of Working Group III of the Intergovernmental Panel on Climate Change (Cambridge: Cambridge University Press).

Johns, T. C., Gregory, J. M., Ingram, W. J., Johnson, C. E., Jones, A., Lowe, J. A., Mitchell, J. F. B., Roberts, D. L., Sexton, D. M. H., Stevenson, D. S., Tett, S. F. B. and Woodage, M. J. (2003) Anthropogenic climate change for 1860 to 2100 simulated with the HadCM3 model under updated emission scenarios, Climate Dynamics, 20, pp. 583-612.

Koppe, C. and Jendritzky, G. (2003) Hitze und Mortalität, Tharandter Klimaprotokolle, 9, pp. 220-2.

Lecha, L. and Shackleford, P. (1997) Climate services for tourism and recreation, WMO Bulletin, 46, pp. 46-7.

Matzarakis, A. (2001) Die thermische Komponente des Stadtklimas. Wiss. Ber. Meteorol. Inst. Universität Freiburg No. 6.

Matzarakis, A. (2002) Examples of climate and tourism research for tourism demands, 15th Conference on Biometeorology and Aerobiology with the International Congress on Biometeorology, 27 October to 1 November, Kansas City, Missouri, pp. 391-2.

Matzarakis, A. and de Freitas, C. R. (Eds) (2001) Proceedings of the First International Workshop on Climate, Tourism and Recreation, International Society of Biometeorology, Commission on Climate Tourism and Recreation, December.

Matzarakis, A. and Mayer, H. (1996) Another kind of environmental stress: thermal stress, WHO Collaborating Centre for Air Quality Management and Air Pollution Control, Newsletters, 18, pp. 7-10.

Matzarakis, A. and Mayer, H. (1997) Heat stress in Greece, International Journal of Biometeorology, 41, pp. 34-9.

Matzarakis, A. and Moya, B. (2002) Concept for a climate tourism index including precipitation, 15th Conference on Biometeorology and Aerobiology with the International Congress on Biometeorology, 27 October to 1 November, Kansas City, Missouri, pp. 28-9.

Matzarakis, A., Mayer, H. and Iziomon, M. (1999) Heat stress in Greece: applications of a universal thermal index: physiological equivalent temperature, International Journal of Biometeorology, 43, pp. 76-84.

Matzarakis, A., Rutz, F. and Mayer, H. (2000) Estimation and calculation of the mean radiant temperature within urban structures, in: R. J. de Dear, J. D. Kalma, T. R. Oke and A. Auliciems (Eds) Biometeorology and Urban Climatology at the Turn of the Millennium, Selected Papers from the Conference ICB-ICUC'99, Sydney, WCASP-50, WMO/TD No. 1026, pp. 273-8.

Mieczkowski, Z. (1985) The tourism climate index: a method for evaluating world climates for tourism, The Canadian Geographer, 29, pp. 220-33.

Murray, R. (1972) A simple summer index with an illustration for summer 1971, Weather, 27, pp. 161-9.

New, M., Hulme, M. and Jones, P. (1999) Representing twentieth century space-time climate variability, Part 1: development of a 1961-1990 mean monthly terrestrial climatology, Journal of Climate, 12, pp. 829-56.

New, M., Hulme, M. and Jones, P. D. (2000) Representing twentieth century space-time climate variability. Part 2: development of 1901-96 monthly grids of terrestrial surface climate, Journal of Climate, 13, pp. 2217-38.

New, M., Lister, D., Hulme, M. and Makin, I. (2002) A high-resolution data set of surface climate over global land areas, Climate Research, 21, pp. 1-25.

Poulter, R. M. (1962) The next few summers in London, Weather, 17, pp. 253-7.

Rackliff, P. G. (1965) Summer and winter indices at Armagh, Weather, 20, pp. 38-44.

Reifsnyder, W. E. (1983) A climatic analysis for backcountry recreation, Biometeorology 8, Part 2 (lectures and reports), Proceedings of the Ninth International Biometeorological Congress, pp. 87-99. 
Shackleford, P. and Olsson, L. E. (1995) Tourism, climate and weather, WMO Bulletin, 44, pp. 239-42.

Terjung, W. H. (1969) Some thoughts on recreation geography in Alaska from a physio-climatic viewpoint, California Geographer, 9, pp. 27-39.

Tinz, B. and Jendritzky, G. (2003) Europa- und Weltkarten der gefühlten Temperatur, in: F.-M. Chmielewski and T. Foken (Eds) Beiträge zur Klima- und Meeresforschung, pp. 111-23 (Berlin and Bayreuth: self published).

VDI (1998) VDI 3787, Part I: Environmental meteorology: methods for the human-biometeorological evaluation of climate and air quality for the urban and regional planning at regional level. Part I: Climate. VDI/DIN-Handbuch Reinhaltung der Luft, Vol. 1b (Düsseldorf: Beuth Verlag).

Yapp, G. A. and McDonald, N. S. (1978) A recreation climate model, Journal of Environmental Management, 7 , pp. 235-42. 